\title{
A BRIEF HISTORY OF MEDIEVAL ROMAN CANON LAW IN ENGLAND
}

In discussing the influence of the Canon law in England, the period of time open for our investigation is those centuries between the Norman Conquest and the Reformation, or from the middle of the IIth to the middle of the I6th century. After the break with Rome by Henry VIII all direct connection with the Vatican is severed. How was the Canon law regarded prior to the Reformation? The investigator who examines simply the field of jurisdiction which the English State allowed the Church to appropriate, and who then finds that in England the Church was not suffered by the State to possess "certain considerable portions of that wide field of jurisdiction claimed by Canonists as the heritage of ecclesiastical law,"1 will probably abandon his investigation with the belief that the Canon law had scarcely any authority in England, so great was the English hostility manifested against it by the State.

But, to get at the truth of the matter, is not this the question to be investigated when considering the influence of the Canon law in England: did the English ecclesiastical courts "hold themselves free to accept or reject, and did they in some cases reject, the Canon law of Rome?"2 The answer is, that the English ecclesiastical courts possessed no such power as that of accepting or rejecting the Canon law-they acknowledged its binding authority on them. Although England curtailed greatly the claims. of jurisdiction advanced by the Church, yet the fact is that within the limits of that curtailed ecclesiastical jurisdiction, the English Church, as a provincial church subordinated (by its own admissions) to the supreme head of the Western Latin Church, administered and rendered obedience to Roman medieval Canon law in the English spiritual courts.

This proposition seems to run squarely against the traditional and generally accepted doctrine on this point,

1 Maitland, Canon law in England, p. 5r.

2 Maitland, $I d$. 
especially that set forth as late as $\mathrm{r} 883$ by the English Ecclesiastical Courts Commission. The following is quoted from this Report: "The laws which guided the English courts up to the time of the Reformation may then be thus arranged: (3) the Canon law of Rome, comprising the Decretum of Gratian; the Decretals of Gregory IX, published in I230; the Sext, added by Boniface VIII; the Clementines, issued in 1318; and the Extravagantes, or uncodified edicts of the succeeding Popes. A knowledge of these was the scientific equipment of the ecclesiastical jurists, but the texts were not authoritative." Here is the point: "not authoritative." The next sentence ought to tell us why by way of illustration. To continue: "The English barons and the king at the Council of Merton refused to allow the national law of marriage to be modified by them (these papal texts), and it was held that they were of no force at all when and where they were opposed to the laws of England." Does this settle the entire matter? The ecclesiastical court had a rule about legitimation of bastards: the temporal justice had another whereby bastards could not be legitimated: evidently there was a clash, and the temporal court conquered (or, in other words, the State finally curtailed the jurisdiction of the ecclesiastical court by sending the objectionable question of legitimacy not to the ecclesiastical court as formerly, but to a jury of twelve men)..

But the English ecclesiastical courts, although failing to obtain a change in the English law of inheritance, keep right on administering in their jurisdiction this rule of the church, and legitimated or recognized this rule of legitimation in a sphere within which the English Church would not come into contact with the secular power. It seems that a man who was not legitimate could not be ordained without a dispensation. What did the English bishops do in this case? Did they recognize the rule of the English temporal law or the law of the Corpus Juris Canonici? The old English Canonists, John of Ayton and John de Burgh, apply the

Vol. I, p. 24, 
medieval Roman ecclesiastical rule, which was enforced in England until the Reformation, or even later if we follow Godolphin in his Repertorium Canonum. Says Maitland on this point:4 "And here it may not be impertinent to ask whether the law which excluded bastards from orders has ever been definitely repealed, and whether our English bishops are actually enforcing it. If a negative answer must be given to both these questions, then I think that we have here a valuable hint as to some of the less obvious among the effects of the Protestant Reformation. An old rule of Catholic Canon law was forgotten or ignored, though no one could have laid his finger on any text by which it was expressly abrogated."

There was a famous English Canonist named William Lynwood, who is an authority on the theory of law which prevailed in the English ecclesiastical courts Ioo years prior to the Reformation. Lynwood was a principal official of the Archbishop of Canterbury at the time he (Lynwood). completed in $143^{\circ}$ his gloss on the provincial constitutions of the archbishops of Canterbury. In regard to the burning of heretics Lynwood says that burning is the punishment prescribed by the Decretals of Boniface VIII. In other words, "heresy was in his view a spiritual crime, and it was for the Church, not for the State, to say what should be done with heretics. If a lay prince refused to execute the Church's law concerning this crime, he was to be excommunicated."' In England the secular power made provision for its duty; the statute of I4OI of Henry IV "authorized the burning of heretics, and those only, who according to 'the canonical sanctions' ought to be relinquished to the secular courts. What were these canonical sanctions? They were the titles de haereticis in the papal law-books." 6

The conclusion from these instances (and others are possible) is, that wherever in England the Church and State fought over the debatable land between spiritual and tem-

- Canon law in England, pp. 55-56.

- Maitland, $I d$., pp. 79-80.

- Maitland, Id., p. 80. 
poral jurisdiction, if the State won (as it did usually), it cultivated the portion obtained as it saw fit, irrespective of any known system of law. But whatever portions of debatable jurisdiction were left to the Church, these it cultivated with but little regard for the secular law, but with great regard and obedience to the statute law of the Pope, its acknowledged head and ruler.

Did the English Church really regard the Papal Decretals as statute law, or did they apply a law of their own, accepting or rejecting any from the Corpus Juris Canonici? It is usually asserted today that the "foreign Canon law" was only applied in England when sanctioned by English custom or approved by the English rulers of the English provincial church: was this actually the theory which prevailed in the English ecclesiastical courts during the later Middle Ages? It is no answer to show how the secular power narrowed and limited the field conceded to ecclesiastical justice and made it smaller than the Popes or Canonists would wish it to be. What we want to see (if there was a national English Canon law peculiar to England) is the spectacle of an English ecclesiastical judge daring to reject a Decretal as infringing the law of the English "Church," or because the "Church" has not received it. Such a historical fact cannot be found.

But in the reign of Henry VIII-after the Reformation-a new doctrine about the Decretals began to prevail in the English spiritual courts: the doctrine that they must be "received" and "approved" in order to have any force at all. What did Cardinal Wolsey do in a case (brought on the very eve of the Reformation) which involved this very question, a case in which it was claimed that the Decretals which exempted clerics from lay justice had never been received in England and had no binding force? Before a convocation of the clergy this assertion was ill-received.7 And yet if this later and current theory was correct, this assertion of Friar Standish should have been favorably

7 Maitland, $I d .$, pp. 87-88. 
received by those who, according to this current theory had maintained it as a primary rule in the ecclesiastical courts. Wolsey himself before the king claimed the "privilegium fori," that is, the clergy ought not to be brought into the secular forum-a practice contrary to the Decretals. ${ }^{8}$

The breach in the continuity of English ecclesiastical affairs came with the Reformation. Thereafter, it, the Canon law, was a foreign law. But before the Reformation, that Canon law was the law of the ecclesiastical courts and applied by them, is the conclusion from history. Lynwood reports no English case law of the English ecclesiastical courts. ${ }^{9}$ He seems to treat the English Church (and he was one of her own judges) as a dependent fragment whose laws had been imposed upon it from without. Maitland calls his (Lynwood's) work "stark Papalism."10 Lynwood wrote his elementary law-book for beginners: in this book he places first, as the head of the authoritative jurisprudence, the Decretals; next, the Legatine constitutions of the English Church (laws enacted by English synods under Cardinals Otho and Othobon, legates of Gregory IV and Clement IV, I220-1228); last, the provincial constitutions (enacted in provincial synods held under the archbishop of Canterbury from Stephen Langton to the Reformation). Lynwood says these last must not contravene the laws of the Popes or legates. Would Lynwood have so described the sources of Canon law in this order, had the view of the Ecclesiastical Courts Commission (who invert the order as given) been the accepted view of his age-r430 A. D.?

The jurisdiction of the Pope of Rome in medieval England: original and appellate. $x$. Original jurisdiction. In the Middle Ages in England, down to the Reformation from the Norman conquest, it is a historical fact that courts were created for the occasion by Papal rescript. Bracton ${ }^{11}$ states an instance as of the reign of Henry III. ${ }^{12}$ Between the

8 Maitland, $I d$., p. 88.

- Maitland, Id., p. 44 .

${ }^{10}$ Maitland, Id., p. 47 .

i1 $f$. 4 I2.

12 Began to reign $1216 \mathrm{~A}$. D. 
years II5O and I240 one small priory is recorded as having no less than I7 ecclesiastical lawsuits before Papal commissioners. ${ }^{13}$ In the year 1245 there died a famous English civilian by the name of William of Drogheda. He wrote a book on procedure, called the Summa, ${ }^{14}$ at about the year 1239; it was intended, in the first instance, for the Oxford University law school. His object was to trace an action from start to finish, and to solve difficulties for the practitioner. He also gave certain forms or models to be employed. It has one very striking feature. "William (of Drogheda) assumes that the first step taken by any English litigant will be the 'impetration' of a Papal writ appointing judges delegate to hear his cause. This 'impetration,' he says, is the head and foundation of the whole procedure, and therefore the first formula he gives us must be a precedent for a letter sent to the court of Rome by a plaintiff who is about to bring an action." 15 He also tells that the plaintiff ought to have a friend at Rome; he tells what to do with the original Papal mandate after it is received. Notice the following similarity between suing out a writ from the Roman chancery with suing out a writ from the English chancery: the writ which started a suit in the English common law court was called "original"; now William of Drodheda uses the very same term for the more ancient Papal writ which was presented to the Papal judge delegate.

Why advise men to go to Rome to start a law suit? William of Drogheda implies three reasons: (I) because sooner or later the law suit will get there (Rome) on appeal; (2) in suits where the parties lived in more than one diocese, inasmuch as the bishops were independent of each other, justice was best had by starting the suit with the Pope who was superior to all bishops; (3) by starting a suit with the Pope the plaintiff "enjoyed a large liberty of choosing his own judges. In his letter of impetration sent to Rome he

${ }^{23}$ Maitland, Canon law in England, p. 107.

14 Maitland, Id., p. Iog.

15 Maitland, Id., pp. III-ri2. 
named the persons whose appointment he desired.15 . . . This, then, is the legal doctrine taught at Oxford University some five or six years after Gregory IX had issued his Code of Decretals. ${ }^{17}$ Drogheda registers the fact that the Pope is the universal court, in order to tell would-be-lawyers how fame and fees are to be won.

How many cases were carried in the first instance before the Pope's delegates, and how many went to the ordinary ecclesiastical courts in England, is not known. ${ }^{18}$ The records of the Papal delegate courts are not found; perhaps they were not carefully preserved, since the court dissolved as soon as a single cause was decided. This "usurpation" of Rome, it is known, was imitated by the archbishop of Canterbury who would make his court a court of original jurisdiction for the whole of his province. ${ }^{19}$

The jurisdiction of the Pope of Rome in medieval England. 2. Appellate jurisdiction. Enormous was the magnitude of the appellate jurisdiction of the Pope over cases. referred or appealed from subordinate English ecclesiastical courts or bishops to him. Out of 470 dated Decretals of Pope Alexander III over one-third, or about I80, were directed to England. ${ }^{20}$ Out of 430 undated letters of the same Pope, 50 per cent. or 215 were sent to England.21 Alexander was Pope II59-II8I A. D., or in the latter half of the I2th century. As Maitland says, "Did these Englishmen (of the I2th and I3th centuries) . . . question the binding force of those statutes books (of the Popes) which, in a great measure, were the outcome of their own submissiveness? Did they treat those books, not as statute books, but as reputable 'manuals'? I have been giving my reasons for thinking that what most Englishmen would regard as the pleasant answer to these questions is not true." 22

16 Maitland, Id., p. Ir4.

17 Maitland, Id., p. I15.

18 Maitland, Id., pp. II6-II7.

19 Maitland, Id., p. II7. Gregory IX

${ }^{20}$ Maitland, $I d .$, p. I23. Those were ratified and sanctioned by Pope ${ }_{21} I d$.

22 Maitland, Id., p.-130. 
Post-Reformation English ecclesiastical law the descendant of medieval Roman Canon law. It is clear that, prior to the Reformation, medieval Roman Canon law was the law of the English Church. Hence the doctrines of that law, especially those belonging to the civil side of Canon law which were derived in large measure or copied from the Civil law of Rome, directly or insensibly affected the development of early modern English ecclesiastical law. The Roman law filtered into England through the agency of Canon law. The "King's ecclesiastical law," which for the last three centuries has been administered in English ecclesiastical courts by force of acts of Parliament, rests on this Canon law of the provincial English Church, which however has been very largely altered, modified, and abolished by acts of Parliament. And the exclusive jurisdiction over the distribution of estates of deceased persons acquired in England by the Church in the Middle Ages-an acquisition hardly aspired to by Canonists elsewhere in Europe-long survived the Reformation and the break with Rome and nearly down to the present time. ${ }^{23}$

Although Henry VIII decided for the Church not only the limits of its sphere of action, but also how and by what law (i. e., English statutes) the separated English Church should act and decide within that sphere of action (a policy followed by his successors), and the "statutory orthodoxy" of Henry VIII compels all judges to say that it was only by "their own consent" that the English people ever paid any attention to Decretals or laws of any "foreign prince, potentate, or prelate," yet the historical fact remains that there was once a juridical bridge between England and Rome, that across this bridge with the Popes walked unseen the majestic, eternal spirit of the Civil law of Rome, and that, when the bridge was cut away, Englishmen tried (and succeeded for a long time) to forget that there ever had been any such authoritative communication between their country and the home of the Caesars.

23 The post-Reformation English ecclesiastical courts were abolished in the year 1857: Sherman, Roman law in the modern world, vol. i, \$\$380, 384, 4 or. 
Influence of medieval Roman Canon law on the development of the secular English Common law and Equity. There is no country in Europe where the secular or civil portion of Canon law (largely Roman Civil law in origin) had such marked, exclusive, and permanent influence as in England. And yet its sphere of action in England was limited, being narrowed again and again by the royal power. In other countries of Europe at some period in their legal historygenerally in comparatively late medieval times-there have been manifested a renewed interest in and a turning to the Roman Civil law in an open manner; in England the Civil law of Rome generally obtained entrance by walking hand in hand with the Canon law,.as a mother walks with her daughter.

I. The Canon law and the Common law. The influence of the Canon law on the Common law of England has been exercised in two ways, sometimes separately, sometimes combined: by attraction and repulsion. The very term "Common law" is borrowed by attraction from the "jus commune" of the Canon law and is a phrase very well-known to Canonists, ${ }^{24}$ referring to the law common to the whole church as opposed to the statutes, special customs, and privileges of any provincial church. The Canonists themselves borrowed the term "jus commune" from the ancient Roman texts. ${ }^{25}$ In Bracton's time the term "Common law" is used infrequently, but in the reign of Edward I (12721307) the term "Common law" is contrasted frequently with statute law and local custom. After a time the temporal courts of the realm became known by the name of "Common law" courts, and the law administered therein "Common law," as opposed to the law of holy Church.

The influence of Canon law by repulsion is seen in Glanvil's statement ${ }^{26}$ of the "Canons and Roman Laws" as opposed to the English laws, especially those made by the

24 Sherman, Roman law in the modern world, vol. i, \$371.

${ }^{25}$ Cod. Theod., 16, 5, 23; Cod. Theod., 2, I, 10.

26 vii, 15. He was Chief Justiciar of Henry II (1133-1189): Sherman, Roman law in the modern world, vol. i, \$372. 
king and barons, which latter he states ${ }^{27}$ are just as much "laws" (leges) as those studied at Bologna. English law became conscious of its existence. It led to the English customs being formulated in writing in the middle of the I2th century.

In the $14^{\text {th }}$ and I5th centuries, the King's justices and practitioners were profoundly ignorant of the Digest and Decretals, although the learned Doctors practising before the spiritual or church courts were not so ignorant of temporal law, which limited their sphere of action. But, in the 12th and I3th centuries, this was not so. Henry II's greatest triumph was that he made prelates of the church his justices. English law during this period was administered by the best-qualified men in the kingdom, in spite of the fact that the knowledge of their own Canon law may have been superficial. Henry II had at one time three bishops for his Chief Justiciars. In Richard II's reign the King's temporal court was composed of the archbishop of Canterbury, two other bishops, two or three archdeacons, two or three clergy about to be bishops, and but two or three laymen.28 The majority of the temporal court of the King, administering the native or "Common law," might have to hear at any time an ecclesiastical cause and learn a lesson in law addressed to them by Papal rescript.

Blackstone's picture ${ }^{29}$ of a nation divided into two parties, "bishops and clergy" on the one side contending for a foreign jurisprudence, and "nobility and laity" on the other adhering "with equal pertinacity" to the old Common law, is not borne out by the facts. Blackstone is wrong. "It is by 'popish clergymen' that our English common law is converted from a rude mass of customs into an articulate system of law, and when the 'popish clergymen,' yielding at length to the Pope's commands, no longer sit as justices of the King's court, the creative age of our medieval law is over." 30

\footnotetext{
$n$ In his Prologue.

23 Pollock and Maitland, Hist. of Eng. law, 3d ed., vol. i, p. I32.

\& Comm., i, I9.

${ }^{30}$ Pollock and Maitland, Hist. of Eng. larw, vol. i, p. r33.
} 
One thing is sure: the legal learning of the King's judges who were ecclesiastics was immeasurably superior to that of their lay fellows in the temporal court; for the clergy in the I2th and I3th centuries constituted the educated class, if by virtue of no other reason than their knowledge of the Latin language which gave them access to the legal treasures of Roman antiquity and the medieval Decretum of Gratian or still earlier Canon law authorities.

Although subsequently in the reign of this same Richard II (I377-I399) it was prohibited to cite any longer the Roman law in the Common law courts, ${ }^{31}$ owing to an outbreak of the national spirit of England against Rome in the latter part of Richard's reign because of the court of Rome's exactions, yet the following statement of Spence, in his Equitable Jurisdiction of the Court of Chancery, ${ }^{32}$ is quite true: "Many of the titles of the Canon law, such as those of buying and selling, of leasing and letting . . . of mortgaging and pledging, of giving by deed of gift, of detecting of collusion . . . of murder, of theft and receiving of thieves, and others (like usury, although they are known notoriously to belong to the cognizance of the Common law of this day), ${ }^{33}$ yet with the matters whereof they treat, were anciently in practice and allowed in bishops' courts in this land amongst clerks. . . . Whether any traditional remembrance of the Roman law, which was preserved in London and other commercial towns, contributed to this must be left to conjecture. When we come to the reign of Henry II we find that many of the Roman doctrines above averted to, particularly . . . letting and hiring, and of pledge, were in operation in the King's Court, and without being noticed as of novel introduction; from thence they became with modifications incorporated in the common law. . . . We can only look to the clerical members of the King's court or ecclesiastical synods, for their introduction, for the vol. $i, \$ 378$.

"Spence, Equity, vol. i, p. 83; Sherman, Roman law in the modern world, ${ }_{22}$ Vol. i, p. 345 .

33 The year 1846 . 
clergy presided as judges in the King's court under the Norman sovereigns."

As to the procedure of the Common law, the conception and practice of suing out an original writ from the temporal court-even the very name "original"-are derived, as we have seen, ${ }^{34}$ from the canonists' procedure of getting a papal writ from Rome, as recommended by the canonist William of Drogheda early in the I2th century. The Canon law brought in the Civil law; it borrowed the greater part of its procedure from the Roman law. When Gratian's Decretum did not suffice, the Canonists went to the Emperor Justinian's law books. A celebrated case in the reign of Richard I (II89-Ir99), brought by the monks of Canterbury against their archbishop, has come down to us: the monks backed up their claims of law by 80 citations to the Decretum, 40 to the Digest of Justinian, 30 to the Code of Justinian. ${ }^{35}$

The English law of procedure was rationalized under the influence of the Canon law. Here and there the one system borrowed a whole set of rules from the other: for example, Glanvilis tells us that "the exceptions" (or, as we would say, the challenges) "which can be made against jurors are the same as the exceptions which can be made against witnesses in the courts Christian."

Again, another mass of rules was borrowed in regard to the science of pleading. The elementary outlines of pleading can be expressed only in terms familiar to civilians and Canonists. William de Longchamp, whom Bracton follows almost verbatim, writes: "Of exceptions (special pleas) some are dilatory, others are peremptory" - the original source of this statement being Justinian's Institutes. ${ }^{37}$ When adopted into the English temporal courts, the peculiar mode of trial prevailing there-trial by jury-gave them a distinctive form.

"see supra this article.

${ }^{25}$ Pollock and Maitland, Hist. of Eng. Zavp; yol. i, p. Ix6.

$36 \mathrm{ii}, \mathrm{I2}$. He lived in reign of Henry II.

37 Inst $4,13,88$. 
Reeves, in his History of English Law,"38 says: "The very idea of such fixed formal requisites of (our Common law) actions is borrowed from the formulae of the Civil law. Their. whole style is framed on these models, and in many instances there is an exact conformity in expression: e. g., the words 'vi et armis' are evidently borrowed from a formula on the Lex Julia as to "vi.".

Stephen on Pleading ${ }^{39}$ is strongly of the opinion that our writs were derived from the Roman law. The terms used in pleading-_"narratio" or "intentio," "exceptio," "replicatio," etc.-were used both by the Civilians and the Canonists.

2. The Canon law and Equity. In the reign of the same king Richard II (1377-I399), when, in the last quarter of the I4th century, it was forbidden to longer cite the Roman law in a Common law court, a new and distinct court was created by statute I7 Richard II, traces of which can be found in the preceding reign of Edward III-namely, the. Court of Chancery. ${ }^{40}$ Probably in part it grew out of the conflict of the courts of Common law with the ecclesiastical courts.

This new court-the Court of Chancery-acting on the principles of the Roman law, took to itself jurisdiction as to trusts involving real property, leaving until very modern times in England the execution of trusts of personal estate, committed to an executor or administrator, to the jurisdiction of the ecclesiastical courts. Perhaps this prohibition of the reign of Richard II against citing in Common law courts the Roman law was intended to exclude the doctrine as to these trusts or fideicommissa.41 But trusts became general in spite of efforts to suppress them, and were administered in this special court of Chancery which applied the excluded Roman law. Rules for the regulations of trusts were necessary; trusts had sprung from the Roman

${ }^{28}$ Vol. i, p. 495 (Finlason).

39 Note 2.

40 Spence, Equity, vol. i, pp. 84, 345.

1 Spence, Equity, vol. i, p. 345 . Fideicommissum is the Roman trust: Sherman, Roman law in the modern world, ii, \$712. 
law; what persons were better fitted to introduce and systematize rules for their regulations than those persons now exclusively conversant with the Roman law, who alone, as it was now excluded from the common law courts, could resort to it for their guidance? "Accordingly," says Spence, "from this time (but with some exceptions tending to affirm the general proposition) none but clerical chancellors were appointed down to the 2Ist year of the reign of Henry VIII" -from I394 to 1530 , a period of nearly 150 years. Had these chancellors been taken from the common lawyers, the modern system of Equity jurisprudence would never have been raised.

It is a frank confession of the debt owed by Equity to the Canon law which Mr. Justice Ware makes in the year I837 in the case of Hutson v. Jordan:43 "Not to insist that the course of proceeding in the courts (he is contrasting Equity with Admiralty) is different in many respects, it is more material to be remarked, that their rules and principles are derived from different sources: those in Equity being derived from the Canon law, through the English ecclesiastical courts, modified it is true from time to time by the court itself, while the general rules of practice in Admiralty come to us directly from the Roman law."

Jurisdiction of English ante-Reformation ecclesiastical courts over spiritual and ecclesiastical matters. The field of English ecclesiastical jurisdiction was extensive. The church tribunals had both civil and criminal jurisdiction. Before the Protestant Reformation, the English ecclesiastical courts had jurisdiction over the following matters: matters of ecclesiastical economy; church property; ecclesiastical dues and tithes; marriage; divorce; legitimation; testate and intestate successions of personal property; contracts involving pledge of faith or oath; various crimes and torts.

I. Matters of ecclesiastical economy. These include ecclesiastical status, ordination and degradation of the clergy,

aguity, vol. i, pp. 345, 347 .

4 I Ware, U. S. Circuit and District Court reports, 385 . 
consecration of bishops, regulations of ecclesiastical corporations and their administration, divine service and spiritual functions: By his victory over Archbishop Becket Henry II (II64) obtained that the right of patronage was not a subject for interference by ecclesiastical courts.

2. Church property. Also by Henry II's victory over Becket, church property, unless mutually. agreed to have been given to alms or charities, was reserved to the secular courts' jurisdiction; and the older ecclesiastical jurisdiction as to church property ceased.

3. Ecclesiastical dues and tithes. Over the management and collection of dues and tithes, the ecclesiastical courts always had jurisdiction.

4. Marriage.44 The ecclesiastical jurisdiction over marriage demands an extended notice. By the middle of the I2th century, while Gratian was composing his Decretum or Concordance of Discordant Canons, ${ }^{45}$ it was the law of England that marriage appertained to the spiritual forum. Henry II never disputed the Church's claim to jurisdiction of marriage, divorce, and legitimacy.

Glanvil46 acknowledges that the ecclesiastical court had exclusive cognizance of whether or not there had been a marriage. In II43 by Papal rescript it was held ${ }^{47}$ that a marriage constituted by mere exchange of words would prevent the parties from contracting a marriage solemnly celebrated in church-a characteristic doctrine of Canon law prior to the Council of Trent. The marriage law of England was thereafter the Canon law. This doctrine of the Canon law that a bare interchange of words was sufficient to constitute a marriage exercised great influence outside the sphere of marriage on other contracts; if not merely a contract to marry, but also an indissoluble marriage, can be made without any formalities, it would seem Index.

"On marriage and divorce, see Bryce, Studies in history and jurisprudence,

15 The less familiar of the two titles of Gratian's work.

16 vii, I3, I4.

47 Pollock and Maitland, History of English lav, vol. i, p. 124 (Letters of John of Salisbury). 
ridiculous to demand more than consenting words as to other agreements. The seeming tendency of this principle as to contracting marriage without formality was to check the formalistic tendencies of the English law of contracts enforced in temporal courts, and to advance the development of the doctrine that the essence of contracts is not really form, but consent.

In the I2th century espousals at Canon law became of two kinds. First, espousal per verba de futuro, which occurs if a man and woman promise to be sometime in the future husband and wife. Second, espousal per verba de presenti, which takes place if they declare that they now at the present moment take each other as husband and wife. This latter transaction was with greatest difficulty dissolved. Espousal by "words of the present tense" was almost as indissoluble as a physically consummated marriage, but not quite sothe Pope could dissolve it. If consummated, it was forever indissoluble. As to espousal by "words of the future tense," should it be followed by physical union of the parties it resulted in a marriage-the presumption being that the promise to marry explained the sexual union.

Prior to the r6th century Council of Trent, the Canon law required no ceremony or rite as a necessity for marriage. If the parties married secretly without the Church's blessing, it was a valid marriage, although the parties were heavily penanced and could be required to marry in the face of the Church. "Decretal"s of Alexander III to the Bishop of Norwich (England): We understand from your letter that a certain man and woman . . . mutually received each other, no priest being present, and no ceremony being performed as the English Church is wont to employ, and then that, before any physical union, another man solemnly married the said woman and had physical union with her. We answer that if the first man and woman received each other by mutual consent directed to time present, saying to each other 'I receive you as mine,' then

$$
\text { 4. C., 3, X., 4, 3. }
$$


the woman ought to be restored to the first man although there was no ceremony or carnal knowledge: for after such a consent she could not marry another. If there was no consent as aforesaid, and no sexual union preceded by consent de futuro, then the woman must be left to the second man." Better a secret marriage, says the Canon law, than the more deadly sin of transitory union or concubinage. From the middle of the I2th century down to the middle of the I6th century and the Council of Trent, this was the law of England as to marriage: no priest, no religious ceremony were necessary to form a valid marriage; the exchange of consent to take effect at once operated to make the parties married, as did the exchange of consent to take effect in the future followed by physical union. Even after Innocent III at the Lateran Council of I2I5 extended over all Christendom the custom of publication of the banns or notice of the intended marriage of the parties, the formless unblessed marriage was still a marriage. ${ }^{49}$ Such a marriage has sur-. vived in our American common-law-marriage, which in New York was recently repealed by statute.

The Council of Trent (I548-I563) laid down certain rules of a different nature as to marriage: ${ }^{50}$ marriage by the Council is made a sacrament; a religious ceremony by a priest is required; two or three witnesses are necessary. Analogous statutes were adopted in England and in several German Protestant states, partly from retaliatory feeling, partly to suppress dissent from the established churches. The English law at the time of the Reformation was abrogated only as far as it "was contrary to the Protestant religion": 51 subject to this restriction the old Canon law of marriage, plus statutes made analogous to the decree of Trent, continued to be administered in the Anglican Church courts in England until far into the Igth century. ${ }^{52}$

Although the Canon law made marriage easy, a formless contract, it created numerous impediments in a manner

$49 \mathrm{C}, 3, \mathrm{X}, 4,3$.

so Stocquart, Siudies in private internat. law, pp. 14, 20.

51 Statute r 567 of Henry VIII, ch. 3I.

62 See Sherman, Roman law in the modern world; vol. i, \$\$401 384, 380 . 
reckless of mundane consequences. These impediments are either consanguinity or affinity.

(I) Consanguinity. The Roman law allowed marriage between persons related in the 4 th degree of relationship. ${ }^{54}$ At the Lateran Council of I2I5 Innocent III decreed that such a marriage is null and void. How is consanguinity reckoned? The early medieval Roman Catholic Church at first adopted that of the Roman law, counting up from either of the persons related to the common stock, and then downwards again to the other, reckoning a degree for each person both ascending and descending; for instance, first cousins are in the 4th degree. ${ }^{54}$ But after its connection with the Germanic nations the Canon law of the Church adopted the Germanic method of reckoning, and it obtained a permanence in England, whence it was adopted into the English and American common law. ${ }^{65}$ Finally Pope Alexander II, in the I2th century, settled a dispute arising in Italy as to the mode of computation of the Church law by deciding in favor of the Canonical, rather than the Roman, mode. Blackstone thus states the Canonical mode of computing relationship, the same being the mode of the Anglo-American Common law: "We begin at the common ancestor and reckon downwards; in whatsoever degree the two persons, or the more remote of them, is distant from the common ancestor, that is the degree in which they are related to each other." 56

(2) Affinity. By the same Lateran Council decree of Innocent III, marriage within the affinity of the first kind (i. e., husband or wife's blood-relations) was forbidden. All other affinities (and there were seven of these kinds of affinity-the second genus being "wives of the kinsmen of the wife") were to be disregarded. ${ }^{57}$ A deceased wife's sister is an affinity, which was also called such in the later Christian Roman law. ${ }^{58}$

\footnotetext{
${ }^{63}$ Sherman, $I d$., vol. ii, $\$ 465$

ot Sherman, Id.

65 Sherman, Id

${ }^{B S} 2$ Comm. 206.

b7 C. $8, \mathrm{X} ., 4, \mathrm{r} 4$.

ss Sherman, Id., $\$ 466$.
} 
The marriageable age at Canon law was I4 years for boys and 12 for girls. ${ }^{59}$ It was presumed that physical consummation was possible at that time, which presumption could be rebutted. No consent of parents was necessary, as in the Roman Civil law. ${ }^{60}$ A marriage below these ages was voidable.

The paraphernalia of the wife in England was thus derived. The Canonists searched the Civil law of Rome and borrowed from it the term paraphernalia to denote the goods which the wife can bequeath.61 But this word was taken from the church courts by the secular courts or courts temporal, and turned to another purpose: it became used to signify the ornaments and personal belongings of the wife which become the husband's should she die before himthe paraphernatia of the fully developed English Common law. ${ }^{62}$

5. Divorce. An exclusive field of Canonical jurisprudence in England was divorce. A validly constituted mar: riage was practically indissoluble. There was no divorce $a$ vinculo: if the marriage was destroyed, it was annulled by the ecclesiastical courts because of some impediment due to consanguinity or to the multitudinous affinities of the Canon law. The only "divorce" known to the Roman church was and is a mensa et thoro-a separation from bed and board which does not enable the spouses to remarry.

6. Legitimation. No English secular court, from the middle of the 12th century onward, had any doctrine of marriage, for it never had to say whether a valid marriage had been contracted. If deciding whether a child could inherit or a woman was entitled to dower, and this question came up, "Was the marriage valid?", it was sent to the ecclesiastical court for decision. Probably in the I3th century both the secular and the ecclesiastical courts were of one

69 A rule borrowed from Roman law: Sherman, $I d$., $\$ 467$.

60 Sherman, Id., $\$ 468$. p. 430 .

61 Lynwood, Provinciale, p. I73; Pollock and Maitland, Hist., vol. ii,

${ }_{62}$ Blackstone, Comm., p. 435. 
accord concerning legitimacy and capacity to inherit; if the Church court said "This child is legitimate," the State in its temporal court said " $\mathrm{He}$ is therefore capable of inheriting." There was one exception, however: the temporal courts would give no retroactive effect to a marriagechildren who were illegitimate could not inherit simply because their parents subsequently married. But the Church courts kept on applying the Roman Civil law rule, called such children legitimate, and so made them eligible for ordination to the priesthood; and the Church courts did this down to the Reformation and the English break with Rome.

7. Testate and intestate successions as to movables. The English ecclesiastical courts claimed the right to pronounce on the validity of wills, to interpret them, and to regulate the doings of the Church's creature, the executor of a will. They were successful in their contention, and finally obtained the whole law of succession as to movables or personal property not only by will but also by intestate succession. The idea of "last will" was inseparably connected with the "last confession." And this ecclesiastical jurisdiction as to testate and intestate succession of personal property did not cease in England until late in the rgth century. ${ }^{63}$ This split the English law of property into halves. The reason why the English ecclesiastical courts did not obtain jurisdiction over real property was because the Royal secular courts extended their attention to land.

In Glanvil's age (the I2th century) the courts ecclesiastical had established an exclusive right to pronounce on the validity of wills. The origin of this churchly jurisdiction cannot be fixed. Selden surmises that it was acquired in King John's time; but this is doubtful and the origin of ecclesiastical jurisdiction in England over wills is lost in obscurity. The famous English canonist Lynwood knew of no act of Parliament granting this right to Church tribunals. ${ }^{64}$ At any rate, with the dawn of the $13^{\text {th }}$ century, testamentary jurisdiction belongs, and belongs ex-

os Sherman, Roman law in the modern world, vol. $i, \$ 380$.

os Pollock and Maitland, History of English Law, vol. ii, p. 341. 
clusively, to the ecclesiastical courts. ${ }^{\circ 5}$ Selden fixes the probate of wills about the time of Henry III. ${ }^{68}$ Before the beginning of Edward I's reign the ecclesiastical courts evolved a regular procedure for the control of executors. ${ }^{67}$

It was well-settled law in England, in the $13^{\text {th }}$ century, that the goods of an intestate were at the disposal of the judge ordinary of the proper ecclesiastical court. The bishops distributed the intestate's property, but frequently entrusted this distribution to the next and best of the intestate's kindred. In 1285 a statute ${ }^{68}$ provided that the ordinary (bishop) should pay off the intestate's debts in the same manner as executors were bound to do so. In I357 by another statute ${ }^{69}$ the ordinary (bishop) was directed to commit the work of administration "to the next and lawful friends" of the dead. By this statute the term "administrator" was introduced as a technical term. The Canonists called our English administrator an executor dativus, and our English executor an executor testamentary.

8. Contracts involving pledge of faith (Christian) or oath. Here the church was repelled with difficulty, but Henry II succeeded in winning a concurrent jurisdiction for his secular courts of contracts confirmed by oath or pledge of faith, afterwards made exclusively the jurisdiction of the courts temporal.

9. Crimes and torts. The correction of sinners was corporal penance for the soul's health. But here the Church was finally unsuccessful. The secular courts thus limited this claim: if they themselves can punish the offense, the courts spiritual are not to meddle with it. But the whole field of sexual crimes and offenses, the fields of heresy and sorcery, and also certain other minor crimes were annexed by the Church courts.

Fornication, adultery, incest, bigamy were ecclesiastical offenses, and the secular courts had nothing to say about

${ }^{65}$ Pollock and Maitland, Id.

Bs Collected works, p. 1671.

${ }^{67}$ Pollock and Maitland, Id., p. 343.

68 Statutes Westminster, II, c. I9; Pollock and Maitland, Id., p. 361.

3I Edrw. III, Statutes I, c. II. 
them. Rape and fornication were in later medieval English law also punished as crimes by the secular courts-thus involving (unless prohibited by statute) the guilty person in a double penalty. Sorcery and unnatural crimes were punished by church tribunals, until Henry VIII took this power away from the Church and gave-it to the Royal secular courts.

Heresy was punished most severely, if the Church tribunals desired to do so: the extreme penalty was to burn. the heretic alive. In the I5th century (just before the Reformation) the English canonist Lynwood had to answer this question: why are heretics burnt? His answer was, in effect, because a certain statute of the Emperor Frederick II had been sanctioned as part of the Canon law by Pope Boniface VIII in a Decretal. ${ }^{70}$ The English law as to heresy was the law of the Western Roman church in her Canon law; and there was no secular English law or procedure on this subject of heresy. Edward II admitted Papal inquisitors to England and the use of torture at the direction of Pope Clement V, to suppress the Knights Templar. ${ }^{71}$

Io. In conclusion. From what has already been mentioned above, it will be observed that, from the middle of the 12th century on in England, a great mass of litigation, of litigation very commonly not strictly ecclesiastical, was handed over to the courts spiritual either native or created by Papal rescript-all of which English ecclesiastical courts administered the Canon law and from which an appeal could be taken to the Roman See itself.

Effect of the Protestant Reformation on English ecclesiastical law and courts. As a result of the I6th century Protestant Reformation, the Catholic Church in England became a separate national church independent of the Pope and subject to only the King and the laws of England. The jurisdiction of the Pope in England was destroyed by the Reformation statutes of Henry VIII, Edward VI; and Eliza-

70 Provinciale de haeret. 5, 5; Pollock and Maitland, History of English law, vol. ii, p. 546 .

$\pi$ Pollock and Maitland, Id., vol. ii, p. 550. 
beth. By the same statutes the doctrine and government of the Church of England were settled. The Sovereign was made the head and Supreme Ordinary of the Church. Queen Elizabeth's Act of Supremacy ${ }^{72}$ gave the Sovereign the jurisdiction, privileges, rights, pre-eminences, prerogatives and powers formerly vested in the Pope of Rome. The Protestant character of the Church was secured by the Articles of Religion ${ }^{73}$ known as the 39 articles, which are today enforced by statute. All Anglican clergymen today must assent thereto.

The ancient ante-Reformation territorial constitution of the Church into provinces and dioceses, together with the ecclesiastical courts and the dignities of bishops and archbishops, was continued so far as these were not modified by statute. ${ }^{74}$ After the Reformation the only ecclesiastical synods authorized were the Convocations of the provinces of Canterbury and York.

In 1532 Henry VIII re-enacted ${ }^{75}$ the system of appeals formulated by the Constitution of Clarendon which provided for appeals from the archdeacon's court to the bishop, archbishop and finally the King, and prohibited all appeals whatsoever to Rome: where these had been made to Rome they were henceforth to go to the King in Chancery. And for the next three centuries appeals from the archbishop's court were heard by the King in Chancery, the Royal authority being represented by a court known as the Court of Delegates, so called because the judges in it were appointed by the King under the great seal: but in $1833^{76}$ this was superseded by the present modern system of appealing to the King in Council, i. e., to the Judicial Committee of the Privy Council.

Before the Reformation the Papal supremacy was recognized in England; but after the Reformation the cardinal

${ }^{72}$ Statutes of I Elizabeth c. I, s. I7 (1558) II Laws of Eng., 382.

${ }^{73}$ I3 Elizabeth, c. I2 (A. D. I57I).

${ }^{74}$ See II Laws of Eng., pp. 383 et seq.

${ }^{75} 24$ Henry VIII, ch. 12, 3-4; 25 Henry VIII, ch. I9, 4-6.

76 Privy Council Appeals Act, I832 (243 William IV, ch. 92). Appeals other than ecclesiastical go to the House of Lords, and not to the Privy Council. 
principle of English ecclesiastical law is the supremacy of the State over the church. Henry VIII placed the ecclesiastical laws on this footing: "Such canons, institutions, ordinances synodal or other ecclesiastical jurisdictions spiritual as yet be accustomed and used here in the Church of England . . . not being repugnant . . . to the laws or statutes of the realm . . . shall be . . . exercised . . . for the time within this realm." 77

Henry VIII intended to have a code of the English ecclesiastical laws made: ${ }^{78}$ but this design was never carried into effect. He obtained power to appoint a commission to decide what of the old laws ought to be retained and what ought to be abolished.79 The work was actually accomplished by a subcommittee of eight in the reign of Edward VI under the name of Reformatio legum ecclesiasticarum, but this never received the royal authority. Although Elizabeth revived Henry's authority for the scheme, the plan was never executed; and thereafter English ecclesiastical law. has remained on the footing assigned to it in the statute of Henry VIII.80

Although the connection between the English church and the Pope was severed by the Reformation, the jurisdiction of the ecclesiastical courts of the Church of England was practically the same as in the ante-Reformation days of the Papal supremacy. Down to the I9th century ecclesiastical jurisdiction in England was of two sorts: criminal and civil.

As to the laity, the criminal jurisdiction of ecclesiastical courts extended to heresy, adultery, incest, fornication, simony, brawling in church or churchyards, and defamation. ${ }^{81}$ The clergy and church wardens were punished criminally by tribunals of the church for offenses connected with their office.

${ }^{27} 35$ Henry VIII, ch. 16.

78 See 25 Henry VIII, ch. 19; 27 Henry VIII, ch. 8.

725 Henry VIII, ch. $x$.

${ }^{80}$ I Elizabeth, ch. I.

81 There were also some minor offenses: II Laws of Eng., p. 504. 
The civil jurisdiction of English ecclesiastical courts ordinarily embraced causes of marriage, divorce, intestate succession, testamentary succession (including legacies and bequests). The Igth century, however, witnessed a very large curtailment of the ecclesiastical jurisdiction. In 1855 the ecclesiastical courts lost their cognizance of defamation. In 1857 all causes of testamentary and intestate succession were transferred to the newly established Court of Probate. ${ }^{82}$ In 1860 the power of ecclesiastical courts to try and punish the laity for brawling was abolished. ${ }^{83}$ And in the same year the ecclesiastical jurisdiction as to marriage and divorce was given to the newly established Divorce Court. ${ }^{81}$ Finally, ecclesiastical courts no longer have power to correct lay persons for moral offenses: ${ }^{85}$ such is inconsistent with modern custom. ${ }^{86}$

Ecclesiastical courts and jurisdiction in the English Colonies of America, later the United States. Although no bishops were sent to the English colonies until I787, and consequently there were no regular ecclesiastical courts in the colonies prior to their I8th century Revolution and separation from the mother country, yet the Bishop of London was the diocesan bishop of the colonists in North America;87 and he was usually named as the ordinary (bishop) in letters appointing the governors of the various colonies in order to provide for the testamentary and matrimonial jurisdiction assigned to the Church of England by English law. In New York state the court of probate is still called the Surrogate's Court-surrogate being the regular name for a deputy ecclesiastical judge.

In the absence of regular ecclesiastical courts in the colonies, their civil courts assumed, so far as was necessary to the welfare of the colonists, much of the civil jurisdiction appertaining to church tribunals in England-the spiritual

8220 and 2 I Victoria, ch. $77, \$ \$ 3$ and 4.

8323 and 24 Victoria, ch. 32, \$1.

8420 and 21 Victoria, ch. 85, \$\$2 and 4.

${ }^{85}$ II Laws of Eng., p. 505.

88 Phillimore v. Machon, I P. D., 48I (1876).

878 Encycl. Britt., p. 863 . 
features of such jurisdiction being disregarded. And a large portion of the mode of practice and rules of the English ecclesiastical courts was adopted in America, and has survived the separation of the Colonies from the mother country.

Charles $P$. Sherman. 